\title{
Nature of crop contents of an amblyceran pigeon louse, Colpocephalum turbinatum (Phthiraptera: Insecta)
}

\author{
Surendra Kumar, Rehmat Ali, Ghazi Khan, and Arun Kumar Saxena* \\ Department of Zoology, Govt. Raza Postgraduate College, Rampur (U.P.). INDIA \\ *Corresponding author. E-mail: akscsir@rediffmail.com \\ Received: May 9, 2017; Revised received: July 21, 2017; Accepted: January 10, 2018
}

\begin{abstract}
Selected haemetophagous phthirapterans have been convicted to act as reservoir and transmitter of pathogens among their hosts. Amblyceran Phthiraptera are generally believed to exhibit varying degree of haemetophagy. The microscopic examination of 100 adults (both sexes) and 47 nymphal instars of an amblyceran louse, Colpocephalum turbinatum revealed their non haemetophagous nature as any red content compatible with host blood was not detected in their crops. The crops of the lice were found packed with only feather barbules. On seven instances the pieces of egg chorion and in 20 cases the presence of epidermal tissue were also detected in crop contents. However, the presence of any triturating agent (any structure which can help in grinding the feather contents) was not noticed. SEM studies on the ventral side of the head of the louse do not indicate the presence of any pointed gear which can be used to pierce the skin blood vessels of host. Present study suggests that few amblyceran species of Phthiraptera are not in haemetophagous in nature.
\end{abstract}

Keywords: Amblycera, Chewing lice, Colpocephalum turbinatum, Pigeon louse, Phthiraptera

\section{INTRODUCTION}

The impact of parasitism of any phthirapteran species on the health and productivity of the host is dependent upon its population density and feading habits. Avian Phthiraptera exhibit considerable diversity with respect to feeding habits. Some species (mostly Ischnocera) are purely feather feeder while others are partly/ exclusively haemetophagous (Kumar et al., 2016). Amblyceran Phthiraptera are generally regarded as haemetophagous species. Selected haemetophagous species reportedly act as reservoir and transmitter of pathogens among their hosts (Clayton et al., 2016). As many as nine species of Phthiraptera reportedly infest the Blue rock pigeon Columba livia (including three amblyceran species e.g. Colpocephalum turbinatum, Hohorstiella lata and Bonomiella columbae). C. turbinatum, is a common Menoponid louse occurring on birds throughout the world (Naz et al., 2010, 2016; Rizvi et al., 2010; Dik et al., 2013, 2017). In the present studies an attempt has been made to record the nature of crop contents of the louse in order to ascertain its feeding habits. SEM studies of the ventral side of the head of the louse have also been performed to observe the nature to its cephalic organs.

\section{MATERIALS AND METHODS}

Five pigeons (Columba livia Gmelin) infested with $C$. turbinatum were subjected to delousing through fumi- gation (Gupta et al, 2007). Adult lice and different nymphal instars were picked up and dissected under Stereozoom trinocular microscope. The crops were taken out and teased on glass slide to examine the contents present in the crops. To record the head gears of C. turbinatum, the adult lice were subjected to SEM (fixed in $2.5 \%$ gluteraldehyde, post fixed in 0.25 phosphate buffer, critically dried, arranged on aluminum stubs covered with double sided tape, coated with gold palladium in Neo Coater and viewed under New JCM 6000 , at 170-270x). The deloused pigeons were released in wild to lead more healthy life. Hence, the study does not come under the preview of Ethical care. It is further categorized that there is no conflict of interest among the authors regarding the heametophagous nature of $C$. turbinatum.

\section{RESULTS AND DISCUSSION}

Microscopic examination of the crop contents of 30 adult males and 30 adult females of $C$. turbinatum revealed the presence of equal size feather barbules. Likewise, the crops of 20 third instar nymphs, 15 second instar nymphs and 12 first instar nymphs were found packed with feather barbules. In addition to feather barbules the crops of seven adults contained pieces of egg chorion. The presence of epidermal debris was detected in the crops of 20 lice. Any red content compatible to host blood was not detected in crops of C. turbinatum (neither in case of adults nor in case 
Table 1. Nature of crop contents of the pigeon louse, Colpocephalum turbinatum.

\begin{tabular}{lccc}
\hline Species & Stage & Nos. examined & Crop Content \\
\hline \multirow{4}{*}{ C. turbinatum } & M & 30 & $\mathrm{Fb}+\mathrm{EC}$ \\
& F III & 30 & $\mathrm{Fb}+\mathrm{EC}$ \\
& N II & 20 & $\mathrm{Fb}$ \\
& N I & 15 & $\mathrm{Fb}$ \\
\hline
\end{tabular}

M-Male, F-Female, NIII-Third instar nymph, NII- Second instar nymph, NI-First instar nymph, Fb- Feather barbules, ED - Pieces of chorion

of nymphal instars). The presence of the body parts of lice of any other insect were also not noticed in the crop contents of the lice. The crops of the lice did not contain any triturating structure (sand, grain, mica etc.) which can be used by the lice for grinding the feather barbules. SEM of ventral side of head of $C$. turbinatum reveals that the clypeal margin bears 6-8 extremely minute setae (Fig. 1). The sub marginal area of labrum bears 6-8 minute spine like setae while inner margin in beset with 14-16 small sized spiniform setae. The mandibles are roughly triangular with sub equal sides. Tips of apices appear densely chitinized but not sharply pointed. The point of articulation lies on the sides of antennal fossa. The post mentum is simple plate like but prementum appears to be divided in two lobes. Single jointed labial palps are prominently developed and bear 5 setae. The paraglossae hang over the mandibles and bear 6-7setae. The pedicels of antennal are prominent; the first flagellomere is cup shaped with clear stalk while the second flagellomere is club shaped and bears numerous tactile pegs, at the tip. Four jointed maxillary palp arise from stipes of the maxilla. The fourth segment of the maxillary palp was comparatively longer $(50 \mu \mathrm{m})$ than first $(23 \mu \mathrm{m})$, second $(16 \mu \mathrm{m})$ and third segment $(11 \mu \mathrm{m})$. The terminal segment bore a tuft of sensory pegs (measuring 6-8 $\mu \mathrm{m})$ at the apex.

On the basis of crop contents the pigeon louse, C. turbinatum does not appear to be haemetophagous in nature. Nelson and Murray (1971) indicated that on the body of pigeons, C. turbinatum feeds on fluffy zone of the feathers of the vent region and did not detect the presence of host blood (as found in case of amblyceran louse, Hohorstiella lata occurring on same host). The louse is reportedly involved in cannibalism and has been reared in vitro condition, on feather diet for several months (Nelson, 1971). Thus, the general remarks of Whiteman and Parker (2004a) that amblycerans feed on epidermal tissues and blood appear to be true in case of many amblyceran lice but not in case of all the amblycerans. Moreover, Whiteman and Parker (2004b) recorded negative relationship between body condition of Galapagos hawks and the abundance of $C$. turbinatum and suspected this relationship to be based on blood feeding habits of $C$. turbiantum . Whiteman et al (2006) further indicated that natural antibody titre

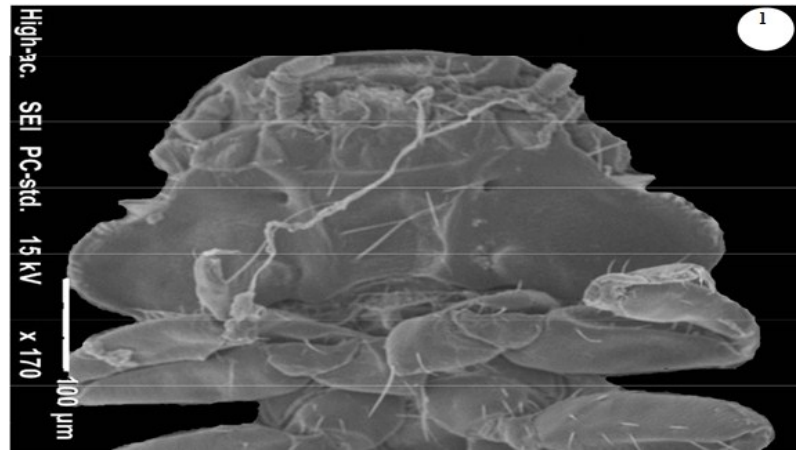

Fig.1. SEM photographs of the ventral side of the head of Colpocephalum turbinatum indicating the nature of cephalic organs.

of Galapagos hawks were found negatively correlated to the abundance of $C$. turbinatum (assuming that it feeds on skin and blood). Santiago et al (2008) also emphasized that $C$. turbinatum feeds on epidermal tissues and blood over most regions of body. Examination of the SEM of the head of aforesaid louse do not indicate the presence of any spinous/ pointed structure which can be used to injure the skins to prepare a blood pool (for ensuring blood diet). Moreover, its mandibles are also not sharply pointed. Being amblyceran, $C$. turbinatum is supposed to exhibit wide distribution on the host body but whether it frequently goes to skin (to derive blood meal) deserves further investigation.

\section{Conclusion}

Haematophagous amblyceran lice do not only affect the vitality and productivity of the birds but are often involved in transmission of pathogens among their hosts. Amblyceran pigeon louse, C.olpocephalum turbinatum occurring on Galopagos hawks has been reported to be haemetophagous in nature. However, the same species of louse parasitizing rock pigeons appeared to be a feather feeder on the basis of the nature of its crop contents. Present studies suggest that few amblyceran Phthiraptera are not haemetophagous in nature.

\section{ACKNOWLEDGEMENTS}

Authors are thankful to Principal, Government Raza P.G. College, Rampur (U.P.) for providing laboratory facilities and to the CSIR, New Delhi for providing financial support to Dr. Surendra Kumar in form of Project (No 37/1659/15EMR II).

\section{REFERENCES}

Clayton, D. H.; Bush, S. E. and Johnson, K. P. (2016). In "Coevolution of life on hosts: Investigating Ecology and history". The University of Chicago Press, Chicago and London, 1-249

Dik, B.; Erciyas- Yavuz, K. and Per, E. (2017). Chewing lice (Phthiraptera : Amblycera : Ischnocera) on birds in the 
Kizilirmak delta, Turkey. Revue Med Vet, 168: 53-62

Dik, B.; Yamac, E. and Uslu, U. (2013). Studies on chewing lice (Phthiraptera : Amblycera : Ischnocera) species from domestic and wild birds of Turkey. Kafkas Univ Vet Fak Derg, 19(4): 553-560

Gupta, N.; Kumar, S. and Saxena, A.K. (2007). Prevalence and population structure of lice (Phthiraptera) on the Indian Red Avadavat. Zool Sci, 24: 381-383

Kumar, S.; Ahmad, A.; Ali, R. and Kumar, V. (2016). A note the haematophagus nature of poultry shaft louse, Menopon gallinae (Amblyera: Phthraptera). J. Parasit. Dis, 12639-016-0760-y

Naz, S.; Rajpar, A. A. and Chandio, A. A. (2016). New records of some Phthiraptera (Chewing lice) of birds from urban areas of Hydrabad, Sindh. Pakistan Panjab Uni. J. Zool, 31(2): 193-201

Naz, S.; Rizvi, S. A. and Sychra, O. (2010). High rate of infestation of chewing lice (Phthiraptera) in Rock pigeons (Columba livia Gmelin 1789) in Pakistan. Trop Zool, 23: 21-28

Nelson, B.C. (1971). Successful rearing of Colpocephalum turbimatum. Nature, 232: 255
Nelson, B.C. and Murray, M.D. (1971). The distribution of Mallophaga on the domestic pigeon (Columba livia). Int J Parasitol, 1: 21-29

Rizvi, S. A. and Naz, S. (2010). The cladistic analysis of Menoponidae (Phthiraptera : Amblycera) found in Karachi region Pakistan. Pak. J. entomol. Karachi, 25(2): 65-80

Santiago, A,D.; Whiteman, N.K.; Parker, P.G.; Ricklefs, R.E. and Valkiunas, G. (2008). Patterns of parasite abundance and distribution in island populations of Galapagos endemic birds. J Parasitol, 91(3): 584-590

Whiteman, N.K.; Matson, K.D.; Bollmer, J.L. and Parker, P.G. (2006). Disease ecology in the Galapagos Hawk (Buteo galapagoensis): Host genetic diversity, parasitic load and natural antibodies. Proc Royal Soc Lond, 273: 797-804

Whiteman, N.K. and Parker, P.G. (2004 a). Effects of host sociality on ectoparasite population biology. J Parasitol, 90(5): 939- 947

Whiteman, N.K. and Parker, P.G. (2004 b). Body condition and parasite load predict territory ownership in the Galapagos hawk. The Condor, 106: 915-921 